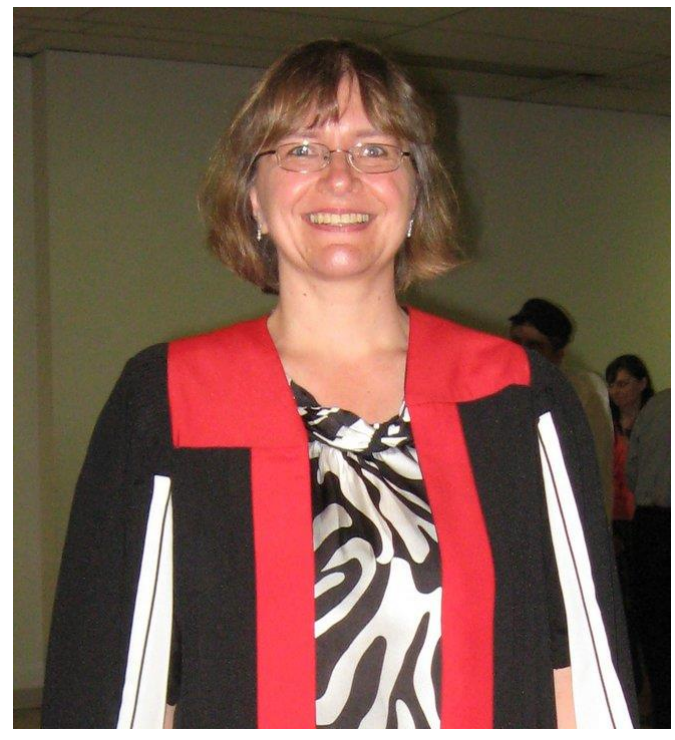

\title{
Profile: Jessica van Keulen
}

\author{
Metadata Specialist, Whitby Project \\ Western University \\ London, Ontario
}

\section{Describe your early background:}

We moved around a lot when I was youngSouthwestern Ontario, Northern Manitoba, The Netherlands-but we always made regular visits to the local public library. Eventually we settled back in London, Ontario. My first real job was as a page at London Public Library's Westown (now Cherryhill) Branch when I was sixteen.

After that, I worked in various retail stores-clothing, office supplies, books, gifts, kitchenware-eventually working my way up to store manager. When our location closed, I decided it was time to choose another career path, so I went back to school and completed the Accelerated Library Technician program at Seneca's Newnham Campus. Several interviews later, I landed a temporary position back in my "hometown" of London, at Western University.

\section{What (or who) influenced you to pursue a career in libraries?}

My mother was a strong influence. She was a special education teacher who went back to school part-time in her forties to get her MLIS (at Western) and became a teacherlibrarian (now retired). At first we didn't have a computer (it was the '80s), so I typed all her essays on an old manual Underwood typewriter. At the time, I was focused on my own studies in Planetary Science (also at Western), so I'm afraid I didn't pay much attention to the contents of those essays, just whether l'd made any typos that would require me to retype the whole page.

When I started re-evaluating my future in retail, the only career I could think of was library work. It would allow me to use my customer service experience, but without the pressure of sales quotas. And I would get to work around books all day!

\section{Where are you working now, and what do you like best about your current job?}

I'm working at Western University on my third temporary contract. My current position is that of Metadata Specialist (Cataloguer), assigned to the Dr. James and Dr. Margaret Whitby Donation. It's a huge (and ongoing) gift of antiquarian music scores. The best 
part of this job is the variety. We have Haydn string quartets, Mozart's operas, plus composers l'd never heard of before, such as Guglielmi, Kospoth, and the Earl of Kelly. There's a lot of research involved and a fair bit of "cataloguer's judgement".

\section{What do you do for recreation?}

I devour books. My tastes in fiction are fairly eclectic-historical romance, urban fantasy, mysteries, high fantasy, etc., but I tend to stick with certain authors. When I discover one I like, I try to find everything they ever wrote, before moving on to another one or re-reading one of my favourites. I also have a collection of coffee-table books on weather, geophysics, nature and movies. I haven't invested in an e-reader yet, mostly because I like the sense of ownership that comes with collecting books. I like the image of the dragon Smaug burrowed in a mountain of gold pieces. That's me, surrounded by shelves and shelves of my books.

\section{Name an interesting book you've read recently. What appealed to you about it?}

The Nine Tailors: A Lord Peter Wimsey Mystery by Dorothy Sayers. It's the fourth or fifth time I've read it, but there's so much detail in her stories. There's the expected dead body, but it's located in the rich setting of the East Anglia fens when England was still reeling from the First World War. And you always meet such interesting people in Sayers' books.

\section{What accomplishment are you most proud of?}

The fact that I took my courage in both hands and went back to school at the age of forty-two. After years of working paycheque to paycheque in retail, I didn't have the financial cushion I would have liked, but I considered it an investment in my future. Now if I could just win the lottery to pay off my student loans, l'd be all set.

\section{If you could travel anywhere in the world, where would you go and why?}

I would go to New Zealand. It's such a dramatic landscape with so much variety in a relatively small area (compared to Canada). l'd have to spend at least a month to see enough. I've always been fascinated with the forces that shape the land. I'm also a fan of the Hobbit and The Lord of the Rings movies, but I spend half my time admiring the background! 